\title{
Seleksi Pejantan Ayam Kampung Berdasarkan Breeding Value terhadap Gerak Massa, Abnormalitas dan Motilitas Spermatozoa
}

\author{
Selection of Free-range Rooster Based on Breeding Value on Mass Movements, \\ Abnormalities, and Motility of Spermatozoa
}

\section{A. A. Zen, Y. S. Ondho, dan Sutiyono}

Departemen Peternakan, Fakultas Peternakan dan Pertanian, Universitas Diponegoro, Kompl. drh. R. Soejono Koesoemowardojo, Tembalang Semarang Kode Pos 50275 Corresponding email: azizzen1@gmail.com

\begin{abstract}
This research aimed to determine the superiority of each free-range rooster based on mass movements, abnormalities, and motility of spermatozoa. This research using 10 free-range roosters. The roosters were 10-12 months old, which were known based on $2-3 \mathrm{~cm}$ of spurs size and $2-2.5 \mathrm{~kg}$ of weight. This research used some equipments consist of individual coop, feeder, bottle, eppendorf tube, beaker glass, pipette, microscope, bunsen burner, object glass, and hand-tally counter. This research used some materials consist of semen, tissue, $2 \%$ eosin, and $\mathrm{NaCl}$ for diluter. This research used non parametric design (One-way ANOVA and Kruskall Wallis). This result showed that the cement volume of each rooster was significantly different $(\mathrm{P} \leq 0.05)$, while the $\mathrm{pH}$, color, consistency, smell, abnormality, and motility of each rooster were not significantly different $(\mathrm{P} \geq 0.05)$. The qualitative and quantitative analysis resulted the total breeding value of each rooster, they were rooster 2 (42), 6 (42), 7 (42), 8 (42), 9 (42), and 10 (42). Based on its total breeding value, chosen the best roosters were rooster $2,6,7,8,9$ and 10 .
\end{abstract}

Key words : free range- rooster, spermatozoa, breeding value

\begin{abstract}
ABSTRAK
Penelitian ini bertujuan untuk mengetahui keunggulan dari masing - masing pejantan ayam kampung berdasarkan gerak massa, abnormalitas dan motilitas spermatozoa. Materi yang digunakan pada penelitian ini yaitu 10 ekor ayam kampung berumur 10-12 bulan, berdasarkan panjang taji 2-3 cm serta bobot badan berkisar 2 $-2,5 \mathrm{~kg}$. Alat yang akan digunakan adalah kandang individu, tempat makan, tempat minum, tabung evendof, bekker glass, pipet, mikroskop, bunsen, object glass, cover glass dan handtally counter. Bahan yang digunakan antara lain semen, tisu, eosin $2 \%$ dan pengencer $\mathrm{NaCl}$. Penelitian menggunakan rancangan non parametrik yaitu One Way ANOVA dan Kruskal Wallis. Hasil penelitian menunjukkan bahwa volume semen dari masing-masing pejantan berbeda nyata $(\mathrm{P} \leq 0,05)$, sedangkan $\mathrm{pH}$, warna, konsistensi, bau, gerak massa, abnomalitas dan motilitas tidak berbeda nyata $(\mathrm{P} \geq 0,05)$. Hasil analisis dari kualitatif dan kuantitatif spermatozoa masing-masing pejantan memiliki total nilai breeding value yaitu ayam 2(42), 6(42), 7(42), 8(42), 9(42), dan 10(42). Berdasarkan hasil penelitian, dapat disimpulkan bahwa ayam yang dipilih adalah dari penilian total breeding value adalah ayam 2 , $6,7,8,9$ dan 10 .
\end{abstract}

Kata kunci: Pejantan Ayam kampung, spermatozoa, breeding value

\section{PENDAHULUAN}

Seiring berkembangnya zaman kebutuhan akan gizi pada masyarakat kian meningkat salah satunya berasal dari produk ternak ayam. Produk ayam adalah daging dan telur yang menjadikan pilihan utama di pedesaan. Pemerintah yang hingga kini sudah berupaya dan berusaha menjalankan berbagai program untuk meningkatkan pembangunan di bidang peternakan unggas.

Ternak unggas seperti ayam kampung adalah ternak yang tergolong sudah ada di berbagai pedesaan di Indonesia. Ayam kampung di berbagai daerah memiliki prospek yang baik untuk dikembangkan dalam upaya peningkatan gizi di masyarakat. Namun dari segi produktivitas ayam kampung dinilai oleh masyarakat masih kurang karena produksi daging yang lambat dan produksi telur sedikit. Masyarakat di pedesaan akhirnya hanya memelihara ayam kampung sebagai sambilan dengan sistem ekstensif yaitu dibiarkan mencari pakan sendiri.

Keunggulan dari ayam kampung adalah mempunyai produk (daging dan telur) yang nilai jualnya relatif mahal. Harga pasaran ditahun 
2019 berkisar antara Rp. 100.000 - Rp. 200.000 /ekor dan telur Rp. 2000 - Rp. 2500 /butir. Keunggulan lainnya sangat pandai mencari pakan sendiri dan mudah beradaptasi. Ayam lokal juga tergolong tahan terhadap penyakit seperti virus H5N1 atau sering disebut flu burung (Nataamijaya, 2010).

Salah satu alternatif untuk meningkatkan populasi dan produktivitas dari ayam kampung adalah seleksi. Proses seleksi merupakan langkah dalam upaya untuk peningkatan mutu genetik ternak ayam kampung yang dilakukan peternak dengan sistem pemeliharaan tradisional sehingga dapat menciptakan bibit unggul (Gunawan et al., 2000). Proses seleksi ayam kampung dipengaruhi oleh faktor internal seperti bobot badan, genetik, dan kualitas sperma

Kualitas sperma merupakan salah satu yang menentukan dari keunggulan genetik dari ayam kampung jantan dalam membentuk ayam kampung unggul sperma yang baik untuk membuahi harus mempunyai kualitas yang baik. Kualitas sperma dapat diuji secara makroskopis dan mikroskopis. Makroskopis antara lain konsistensi, volume, $\mathrm{pH}$ dan warna, sedangkan mikroskopis adalah konsentrasi, viabilitas, motilitas dan abnormalitas. Motilitas sperma normal yang baik direkomendasikan untuk menghasilkan fertilitas tubuh 60-80\% (Hafez, 2000), sedangkan persentase abnormalitas yang masih baik dan dapat digunakan sebagai IB berada dibawah 20\% (Saleh dan Sugiyatno, 2006). Kualitas dan kuantitas semen yang baik merupakan penentu dari terbentuknya anak ayam kampung unggul yang banyak.

Tujuan dari penelitian ini adalah untuk mengetahui keunggulan dari masing - masing pejantan ayam kampung berdasarkan gerak massa, abnormalitas dan motilitas spermatozoa. Manfaat dari penelitian ini adalah dapat digunakan sebagai memilih pejantan berdasarkan kualitas semen dan breeding value dari pejantan ayam kampung yang baik.

\section{METODE PENELITIAN}

Penelitian dilaksanakan pada bulan Oktober 2018 sampai Februari 2019, di Kandang Penelitian Ayam dan Laboratorium Terpadu, Universitas Darul Ulum Islamic Centre, Ungaran, Kabupaten Semarang. Materi yang digunakan dalam penelitian ini adalah 10 ekor pejantan ayam kampung. Kriteria materi penelitian ialah umur 10-12 bulan, dengan dilihat dari panjang taji $2-3 \mathrm{~cm}$ serta bobot badan berkisar $2-2,5 \mathrm{~kg}$.

Peralatan yang akan digunakan adalah kandang individu, tempat makan, tempat minum, tabung eppendof, bekker glass, pipet, mikroskop, bunsen, object glass, cover glass dan handtally counter. Bahan yang digunakan antara lain semen, tisu, eosin $2 \%$ dan pengencer $\mathrm{NaCl}$.

\section{Metode Penelitian}

Metode yang digunakan adalah obsevarsi secara identifikasi dalam menentukan keunggulan masing - masing pejantan berdasarkan parameter kualitas dan kuantitas dari ayam penghasil semen. Pemeliharaan pada masing-masing pejantan dengan cara dipelihara di dalam kandang individu. Ayam jantan yang sudah dimasukkan ke dalam kandang individu kemudian dibiarkan selama dua minggu agar dapat beradaptasi. Selama pemeliharaan pejantan ayam kampung di beri pakan sebanyak 120gr/hari dengan komposisi pakan dedak PK $11 \%$ dan ME $2100 \mathrm{kkal} / \mathrm{g}$, jagung kuning PK 8,9\% dan ME $3350 \mathrm{kkal} / \mathrm{g}$, pakan komersil Hipro-vite PK 17,5\% Ca 0,90\% dan P 0,60\% dan diberi minum saat pagi pukul 07.30 WIB dan sore hari pukul 16.00 WIB.

Pengambilan data dilakukan dengan cara penampungan semen yaitu massage atau pijat sampai keluar sperma. Penampungan semen pada ayam pejantan dilakukan setiap 2 hari sekali dengan 5 kali ulangan. Penampungan tidak dapat dilakukan dalam kurun waktu sehari, maka jadwalnya dibagi menjadi dua kelompok penampungan. Dari penampungan tersebut memiliki umur yang berbeda sehingga untuk menyamakan umur sperma maka yang ditampung setiap ekor ayam pejantan pada kelompok penelitian diambil dua hari sebelum pengambilan data yang spermanya dibuang, sehingga umur sperma yang diambil untuk penelitian menjadi sama umurnya. Sperma hasil penampungan diuji secara makroskopis dan mikroskopis.

\section{Parameter yang Diamati}

Parameter penelitian meliputi makroskopis dan mikroskopis. Pengukuran mikroskopis gerak massa, motilitas dan abnormalitas dilakukan pengukuran oleh 3 orang panelis untuk menghindari data yang bersifat subyektif. (a) Volume semen dihitung dengan cara melihat semen yang ditampung dengan tabung evendorf, kemudian melihat skala yang ada dengan satuan milliliter (ml). (b) Bau semen diamati dengan cara mencium aroma dari semen 
ayam kampung itu sendiri dimana bau spermin (baik), bau amis dan busuk (buruk). (c) Warna semen diamati dengan melihat secara langsung pada semen yaitu dengan kriteria warna kuning pekat dan putih kuning (kualitas baik) dan merah (kualitas buruk). (d) Konsistensi dilakukan pengamatan dengan cara menggoyangkan tabung pada semen yang sudah ditampung ditabung eppendorf secara pelan dengan membentuk sudut $90^{\circ}$, kemudian diamati kekentalannya yang baik (kental dan sedang) serta kurang baik (encer). (e) Uji pH dilakukan dengan cara semen diteteskan pada kertas $\mathrm{pH}$, selajutnya diamati pada skala $\mathrm{pH}$ indikator. (f) Gerak massa dilakukan dengan meneteskan satu tetes semen dan satu tetes $\mathrm{NaCl}$ diletakkan diatas gelas objek kemudian ditutup dengan cover glass. Gelombang yang ada diamati dengan menggunakan mikroskop dengan perbesaran 10 x 40 (400X). Gelombang (+) cukup, (++) baik dan (+++) sangat baik. (g) Uji motilitas dilakukan dengan meneteskan satu tetes semen dan satu tetes $\mathrm{NaCl}$ diletakkan diatas gelas objek kemudian ditutup dengan cover glass. Motilitas spermatozoa dinilai dengan cara subjektif kuantitatif gerak progresif dari lima lapang pandang menggunakan mikroskop dengan perbesaran 10 x 40 (400X). Penilaian dilakukan dengan membandingkan spermatozoa yang bergerak progresif dengan gerakan lain yang tidak progresif dan dinyatakan dalam presentase (\%).

Uji persentase abnormalitas sperma, dilakukan dengan cara membuat prerparat ulas dan pewarnaan. Prosedurnya adalah semen diteteskan pada preparat kemudian ditambah eosin 2\% selanjunya di amati di bawah mikroskop dengan perbesaran 40X. Kriteria morfologi yang diamati antara lain sperma normal, kepala (rusak, patah, pecah dan berkait) dan ekor (melingkar, putus dan patah). Rumus persentase abnormalitas :

Persentase abnormalitas sperma $=\frac{\text { Jumlah sperma yang abnormal }}{\text { total jumlah sperma yang dihitung }} \times 100 \%$

\section{Analisis Data}

Analisis yang digunakan adalah untuk membandingkan keunggulan dari masing masing pejantan yam kampung ada 2. Secara kuantitatif yaitu dengan metode One Way ANOVA, sedangkan data kualitatif dengan Kruskal Wallis. Keunggulan dari pejantan ayam kampung ditentukan secara breeding value berdasarkan gerak massa, abnormalitas dan motilitas spermatozoa.Rumus Kruskal Wallis dan One Way Anova Sebagai berikut:

Kruskal Wallis $(K)=(\mathrm{N}-1) \frac{\sum_{\mathrm{i}=1}^{\mathrm{g}} \mathrm{ni}(\mathrm{ri}-\mathrm{r})^{2}}{\sum_{\mathrm{i}=1}^{\mathrm{g}} \sum_{\mathrm{j}=1}^{\mathrm{ni}} \mathrm{ni}(\mathrm{rij}-\mathrm{r})^{2}}$

Keterangan :

ni : Jumlah pengamatan dalam kelompok

rij : Peringkat (diantara semua pengamatan) pengamatan $\mathrm{j}$ dari kelompok $\mathrm{i}$
$\mathrm{N} \quad$ : Jumlah pengamatan disemua kelompok

Penilaian breeding value pejantan ayam kampung berdasarkan urutan parameter yang sangat penting sampai tidak terlalu penting untuk fertilisasi (membuahi). Pemberian nilai untuk parameter berdasarkan urutan dan cara penilaiannya adalah sebagai berikut :

Motilitas, parameter yang sangat penting karena dapat membuahi yang disebabkan oleh gerak motilitas progesif. Nilai breeding value dari motilitas tertinggi adalah 15 .

Gerak massa, menunjukkan banyaknya sperma yang hidup dan mempunyai korelasi dengan gerak sperma yang maju, namun tidak lebih penting dari motilitas. Nilai breeding value dari gerak massa tertinggi adalah 12 .

Tabel 1. Rumus one way anova (anova satu arah)

\begin{tabular}{lllll}
\hline Source of Varian & SS & Df & Mean square & Fratio \\
\hline Between/grup & SSB/SSG & k-1 & MSB $=\frac{\text { SSG }}{\mathrm{k}-1}$ & F $=\frac{\text { MSG }}{\text { MSW }}$ \\
Withtin & SSW/SSE & $n-k$ & MSW $=\frac{\text { SSW }}{n-1}$ & \\
Total & SST & $n-1$ & & \\
\hline
\end{tabular}


1. Abnormalitas merupakan faktor yang mempengaruhi dalam hal membuahi, tetapi tidak lebih penting dari gerak massa. Nilai breeding value dari abnormalitas tertinggi adalah 10 .

2. Volume, banyaknya semen yang dapat berpengaruh terhadap perkawinan IB, sehingga lebih efektif untuk perkawinan yang lebih banyak. Nilai breeding value dari volume tertinggi adalah 8 .

3. $\mathrm{pH}$, indikasi derajat keasamaan yang dimiliki oleh sperma yang dipengaruhi oleh lingkungan. Nilai breeding value dari $\mathrm{pH}$ adalah 6.

4. Warna dan konsistensi, memiliki kepentingan yang sama. Parameter ini dapat menunjukkan banyaknya sperma yang berada di dalam semen. Nilai breeding value dari warna dan konsistensi tertinggi adalah 3.

5. Bau, indikasi dari layak atau tidaknya sperma yang akan digunakan dengan nilai breeding value tertinggi adalah 1 .

\section{HASIL DAN PEMBAHASAN}

\section{Evaluasi Semen Segar Ayam Kampung}

Hasil rata-rata makroskopis semen segar ayam kampung dilihat dari sifat kualitatif seperti volume, konsistensi, $\mathrm{pH}$, warna dan bau disajikan pada Tabel 2. Dari Tabel 2, tampak bahwa volume semen berbeda nyata $(\mathrm{P} \leq 0,05)$. Hasil penelitian juga menunjukkan bahwa rataan volume semen ayam kampung terendah yaitu ayam $9(0,16 \pm 0,09)$ dan rataan tertinggi adalah ayam $5(0,72 \pm 0,18)$. Hasil rataan volume dari keluruhan individu berkisar antara 0,16 - 0,72 ml. Hasil ini lebih tinggi dari hasil penelitian Khairi et al. (2014) dengan rata-rata volume semen ayam yakni 0,42 ml Kismiati (1997) melaporkan volume sperma per ejakulat yakni $0,11-1 \mathrm{ml}$. Ayam 5 memiliki rataan tertinggi dan yang paling unggul diantara tiap individu pejantan lainnya yakni 0,72 dengan nilai breeding value 7 . Hasil breeding value dari ayam 5 dikarenakan adanya perbedaan genetik, bobot badan ternak tiap individu ayam pejantan. Menurut Toelihere (1993) menyatakan bahwa hasil dari volume sperma ayam berbeda - beda dikarenakan bangsa dari unggas itu sendiri. Menurut Hijriyanto (2017) melaporkan bahwa banyaknya volume tergantung pada breed dari unggas tersebut.

Berdasarkan Tabel 2, Menunjukkan bahwa $\mathrm{pH}$ semen ayam kampung tidak berbeda nyata $(\mathrm{P} \geq 0,05)$. Hasil rataan $\mathrm{pH}$ sperma ayam jantan kampung berkisar antara 7,58 -8,18. Hasil tersebut masih tergolong baik karena masih sesuai dengan standar yakni 7,5 - 7,8 (Hidajat, 2000) . Pada Tabel $2 \mathrm{pH}$ dari masing-masing individu memiliki nilai breeding value yang sama yaitu 5. Menurut Toelihere (1981) menyatakan bahwa derajat keasaman $(\mathrm{pH})$ semen dipengaruhi oleh proses metabolisme spermatozoa yang berlangsung secara anaerobik. Proses metabolisme spermatozoa yang berlangsung sampai hasil akhir menghasilkan asam laktat. Peningkatan $\mathrm{pH}$ (derajat keasaman) dan menurunkan $\mathrm{pH}$ larutan terjadi disaat semakin tinggi Asam laktat yang dihasilkan dan menyebabkan penimbunan Johari et al. (2009).

Tabel 2. Rata-rata makroskopis semen segar Ayam Kampung

\begin{tabular}{|c|c|c|c|c|c|}
\hline \multirow{2}{*}{$\begin{array}{l}\text { No. } \\
\text { Ayam }\end{array}$} & \multicolumn{5}{|c|}{ Variabel } \\
\hline & Volume (ml) & $\mathrm{pH}$ & Warna & Konsistensi & Bau \\
\hline 1 & $0,30 \pm 0,16^{\mathrm{ab}}$ & $8,12 \pm 0,23^{\mathrm{a}}$ & Putih kuning $^{\mathrm{a}}$ & Kental $^{\mathrm{a}}$ & Spermin $^{\mathrm{a}}$ \\
\hline 2 & $0,42 \pm 0,19^{\mathrm{abc}}$ & $7,92 \pm 0,30^{\mathrm{a}}$ & Putih kuning ${ }^{a}$ & Kental $^{\mathrm{a}}$ & Spermin $^{\mathrm{a}}$ \\
\hline 3 & $0,42 \pm 0,11^{\mathrm{abc}}$ & $7,74 \pm 0,36^{\mathrm{a}}$ & Putih kuning $^{\mathrm{a}}$ & Sedang $^{\mathrm{a}}$ & Spermin $^{\mathrm{a}}$ \\
\hline 4 & $0,50 \pm 0,12^{\mathrm{bc}}$ & $7,66 \pm 0,46^{\mathrm{a}}$ & Putih kuning ${ }^{a}$ & Sedang $^{\mathrm{a}}$ & Spermin $^{\mathrm{a}}$ \\
\hline 5 & $0,72 \pm 0,18^{c}$ & $7,58 \pm 0,50^{\mathrm{a}}$ & Putih kuning ${ }^{a}$ & Encer $^{\mathrm{a}}$ & Spermin $^{\mathrm{a}}$ \\
\hline 6 & $0,20 \pm 0,10^{\mathrm{ab}}$ & $7,72 \pm 0,53^{\mathrm{a}}$ & Putih kuning & Kental $^{\mathrm{a}}$ & Spermin $^{\mathrm{a}}$ \\
\hline 7 & $0,34 \pm 0,19^{a b}$ & $7,68 \pm 0,44^{\mathrm{a}}$ & Putih kuning $^{a}$ & Sedang $^{\mathrm{a}}$ & Spermin $^{\mathrm{a}}$ \\
\hline 8 & $0,40 \pm 0,16^{\mathrm{ab}}$ & $7,74 \pm 0,35^{\mathrm{a}}$ & Putih kuning ${ }^{a}$ & Sedang $^{\mathrm{a}}$ & Spermin $^{\mathrm{a}}$ \\
\hline 9 & $0,16 \pm 0,09^{\mathrm{a}}$ & $7,84 \pm 0,41^{\mathrm{a}}$ & Putih kuning $^{\mathrm{a}}$ & Kental $^{\mathrm{a}}$ & Spermin $^{\mathrm{a}}$ \\
\hline 10 & $0,28 \pm 0,13^{\mathrm{ab}}$ & $8,18 \pm 0,33^{\mathrm{a}}$ & Putih kuning & Kental $^{\mathrm{a}}$ & Spermin $^{a}$ \\
\hline
\end{tabular}


Berdasarkan Tabel 2, tampak warna semen pada ayam kampung tidak berbeda nyata $(\mathrm{P} \geq 0,05)$. Rataan warna semen ayam kampung adalah putih kuning dan mendapatkan nilai breeding value yang sama yaitu 3. Hasil dari warna semen yang berwarna putih kuning sudah relatif baik. Menurut Johari et al. (2009) menjelaskan bahwa sperma yang berkualitas baik adalah yang memiliki warna putih krem. Menurut Supriatna (2000) melaporkan bahwa warna krem sperma ayam dan tidak tembus cahaya merupakan yang baik dan menunjukkan konsentrasi yang tinggi.

Dari Tabel 2, diketahui bahwa konsistensi sperma ayam kampung menunjukkan tidak berbeda nyata $(P \geq 0,05)$. Rataan yang diperoleh tiap individu pejantan berbeda-beda antara lain kategori kental dan diartikan baik dimiliki oleh ayam 1, 2, 6, 9 dan 10. Menurut Johari et al. (2009) bahwa konsistensi sperma pada ayam yang baik adalah kental dan tidak tembus cahaya (Suprijatna et al., 2005). Ayam yang memiliki konsistensi kental mempunyai nilai breeding value 3. Ayam yang memiliki konsistensi yang kental dapat berpengaruh pada konsentrasi sperma. Rosiqoty (2001) menjelaskan kekentalan (konsistensi) sperma bahwa jika kental menunjukkan konsentrasi tinggi dan sebaliknya jika encer maka konsentrasi sperma tersebut rendah.

Berdasarkan pada Tabel 2, diperoleh hasil bau semen ayam kampung tidak ada perbedaaan yang nyata $(P \geq 0,05)$. Rataan yang didapat pada bau semen ayam kampung tiap individu adalah bau khas spermin dan memperoleh nilai breeding value yang sama yakni 1. Bau spermin dari tiap pejantan sesuai dengan hasil penelitian Nugroho et al. (2016) menyatakan bahwa bau semen ayam kampung yang normal adalah bau khas. Lebih lanjut Octa et al. (2014) bahwa semen ayam yang baik memiliki bau khas. Bau khas spermin merupakan hasil yang ditimbulkan dari ternak ayam tersebut. Menurut Garner dan Hafez (1993) menyatakan kualitas bau spermin ditentukan oleh genetik dari ayam tersebut.

Hasil rata-rata mikroskopis semen segar ayam kampung dilihat dari sifat kuantitatif seperti gerak massa, abnormalitas dan motilitas disajikan pada Tabel 3. Berdasarkan Tabel 3, Diketahui motilitas sperma ayam kampung tidak berbeda nyata $(\mathrm{P} \geq 0,05)$. Nilai breeding value tiap pejantan sama yaitu 15. Hasil rataan tertinggi terdapat pada Ayam 8 yakni $86,33 \%$ dan membuktikan bahwa yang paling unggul diantara pejantan lainnya. Hasil tersebut sejalan dengan pendapat Iratuti (2007) motilitas yang baik adalah $80 \%$ - $100 \%$ dan lebih tinggi yang dilaporkan oleh Bahr dan Kast (1987) yakni 60$80 \%$ serta menyerupai hasil Abdillah (1996) berkisar antara $80-85 \%$. Motilitas sangat penting dalam penilaian karena sebagi tolak ukur di perkawinan IB (Inseminasi Buatan). Hal ini sesuai dengan pendapat Sopiyana et al. (2006) bahwa salah satu parameter penting (patokan) dasar penilaian dalam perkawinan IB adalah pengujian motilitas. Faktor -faktor yang mempengaruhi tinggi rendahnya motilitas spermatozoa ayam adalah genetik tiap pejantan itu sendiri dan penilaian subyektif dari panelis yang melakukan pengamatan. Hal ini sejalan dengan Salisbury dan Vandemark (1985) yakni perhitungan dalam metode pengujian motilitas dengan cara perbandingan dan hasil yang ditetapkan tidak mutlak.

Dari Tabel 3, tampak bahwa abnormalitas sperma ayam kampung menunjukkan tidak ada perbedaan yang nyata $(\mathrm{P} \geq 0,5)$ sehingga dalam nilai breeding value breeding value masing -masing pejantan mendapat nilai 7 - 8. Dilihat dari rata - rata Ayam 7 adalah yang paling unggul dengan

Tabel 3. Rata-rata mikroskopis semen segar Ayam Kampung

\begin{tabular}{cccc}
\hline \multirow{2}{*}{ No. Ayam } & \multicolumn{3}{c}{ Variabel } \\
\cline { 2 - 4 } & Motilitas $(\%)$ & Abnormalitas $(\%)$ & Gerak Masssa $(+)$ \\
\hline 1 & $85,00 \pm 2,67$ & $16,92 \pm 1,73$ & + \\
2 & $83,67 \pm 5,16$ & $17,50 \pm 1,59$ & + \\
3 & $82,67 \pm 5,63$ & $19,74 \pm 3,77$ & + \\
4 & $82,67 \pm 5,30$ & $16,97 \pm 3,64$ & + \\
5 & $86,00 \pm 4,31$ & $14,35 \pm 3,83$ & + \\
6 & $85,67 \pm 5,30$ & $14,14 \pm 2,68$ & + \\
7 & $84,00 \pm 5,07$ & $13,39 \pm 3,83$ & + \\
8 & $86,33 \pm 3,52$ & $13,61 \pm 2,55$ & + \\
9 & $84,00 \pm 5,73$ & $14,28 \pm 4,02$ & + \\
10 & $86,00 \pm 3,87$ & $13,83 \pm 3,33$ & + \\
\hline
\end{tabular}


persentase $13,39 \%$ lebih rendah dibanding dengan dengan penjantan lainnya. Hasil tersebut terbilang tinggi dibanding dengan hasil 6,13\% 6,27\% (Hanum, 2001), namun sudah berada di kisaran normal yaitu tidak lebih dari 15\% (Evans dan Maxwell, 1987). Menurut Toelihere (1993) yang menyatakan bahwa persentase spermatozoa abnormal berkisar antara 5-20\% per ejakulat yang dapat digunakan untuk IB dan Bearden dan Fuquay (1984) menyatakan bahwa jika abnormalitas sperma lebih dari $25 \%$ satu ejakulasi, maka dapat menurunkan fertilitas.

Abnormalitas spermatozoa pada ayam umunya adalah ekor putus, kepala tanpa ekor, ekor melingkar. Menurut Hafez (1993) abnormlitas tediri dari abnormalitas primer yang terjadi saat proses spermatogenesis ditandai dengan kepala kecil atau terlalu besar, ekor atau badan ganda, sedangkan abnormalitas sekunder terjadi pada saat ejakulasi ditandai dengan butiran protoplasma pada pangkal ekor sperma di caput epididimis. Tingginya hasil rata-rata $13,39 \%$ hingga $19,74 \%$ dipengaruhi oleh beberapa faktor salah satunya adalah suhu. Suhu ketika melakukan penampungan semen penelitian di titik terendah adalah $22,2^{\circ} \mathrm{C}$ dan tertinggi $31,9^{\circ} \mathrm{C}$. Menurut Gilbert (1980) bahwa temperatur dapat berpengaruh terhadap aktivitas reproduksi.

Lebih lanjut Yuwanta (2004) menyatakan bahwa ayam merupakan hewan unggas homiothermic artinya memiliki suhu tubuh yang konstan yaitu $40^{\circ} \mathrm{C}-41^{\circ} \mathrm{C}$. Etches (1996) menyatakan bahwa testis yang berada didalam tubuh dan berlangsungnya proses spermatogenesis pada ayam terjadi saat temperatur tubuh $41^{\circ} \mathrm{C}$. Faktor lainnya yang dapat mempengaruhi abnormalitas spermatozoza adalah kelembaban. Toelihere (1981) menyatakan tingginya suhu udara dikarenakan kelembaban yang tinggi mampu menyebabkan gagalnya pembentukan serta penurunan produksi spermatozoa.

Dari hasil analisis Tabel 3, gerak massa sperma dari tiap individu ayam kampung tidak berbeda nyata $(\mathrm{P} \geq 0,5)$. Dilihat dari rata-rata berkisar antara $1-1,4(+)$, namun jika dilihat dari rataan yang tertinggi dimiliki oleh ayam A2 yakni 1,4. Hasil tersebut masih kurang baik dibanding dari hasil (+++) untuk gerak massa Ervandi (2000). Menurut Evans dan Maxwell (1987) bahwa kualitas sperma yang baik memiliki gerak massa yaitu (++) atau (+++). Gerak massa merupakan gerakan yang ditimbulkan oleh gerak progresif dari spema itu sendiri. Hal ini sesuai dengan pendapat Mardalestari (2005) menjelaskan bahwa gerak massa yaitu cerminan dari gerak individu spermatozoa. Aglutinasi sering juga menyebabkan tidak adanya pergerakan massa sperma ayam. Hal ini sesuai dengan pendapat Supriatna (2000) bahwa gerak massa adalah (+), namun bukan gerak massa melainkan gerak individual dan ini dapat terjadi karena adanya aglutinasi pada sperma ayam yang menyebakan tidak adanya pergerakanan. Semakin aktif spermatozoa yang bergerak sehingga dapat terlihat tebal. Pergerakan spermatozoa yang semakin progresif dan bergerak cepat serta membentuk gelombang massa yang tebal meruapakan kriteria baik hingga sangat baik (Toelihere, 1985).

\section{Penilaian Total Kualitas Spermatozoa dengan Breeding Value}

Penentuan penilaian breeding value secara keseluruhan baik secara mikroskopis dan makroskopis kualitas spermatozoa ayam kampung. Hasil total penilaian dapat dilihat pada Tabel 4.

Berdasarkan Tabel 4, diketahui bahwa penilaian total hasil tertinggi dimiliki oleh ayam $2,6,7,8,9$ dan 10 yang memiliki nilai total breeding value yaitu 42 . Individu ayam tersebut lebih baik dari pada ayam 1, 3, 4 dan 5 dengan nilai breeding value sama yakni 41. Makrokopis dan mikroskopis yang dimiliki oleh ayam 2, 6, 7, 8, 9 dan 10 relatif baik sehingga menjadikan lebih unggul dibandingkan yang lain. Pada Tabel 4, tampak bahwa ayam 5 memiliki nilai volume yang tinggi. Volume yang banyak sangat berguna dalam proses perkawinan IB. Semakin banyak volume semen yang dihasilkan dalam sekali ejakulat dapat digunakan dalam beberapa proses IB di bandingkan dengan volume semen yang rendah. Menurut Nugroho et al. (2016) bahwa perkawinan insemiansi buatan umumnya membutuhkan volume sebanyak $0,1 \mathrm{ml}$. Namun, ayam 5 memiliki konsistensi yang encer sehingga menyebabkan penilaian secara keseluruhan menjadikan tidak lebih unggul dibandingkan dengan individua ayam yang lainnya. Dari Tabel 4 diperoleh Hasil ini menunjukkan bahwa ayam 2, 6, 7, 8, 9 dan 10 jauh lebih unggul dan berpontensi sebagai pejantan untuk dikawinkan karena akan mewariskan untuk generasi selanjutnya. 
Tabel 4. Total nilai breeding value spermatzoa Ayam Kampung

\begin{tabular}{lcccccccccc}
\hline \multirow{2}{*}{ Parameter } & \multicolumn{10}{c}{ Ayam } \\
\cline { 2 - 11 } & 1 & 2 & 3 & 4 & 5 & 6 & 7 & 8 & 9 & 10 \\
\hline Kuantitatif & & & & & & & & & & \\
$\quad$ Motilitas & 15 & 15 & 15 & 15 & 15 & 15 & 15 & 15 & 15 & 15 \\
Abnormalitas & 7 & 7 & 7 & 7 & 8 & 8 & 8 & 8 & 8 & 8 \\
$\quad$ Volume & 5 & 6 & 6 & 6 & 7 & 5 & 6 & 6 & 5 & 5 \\
$\quad$ Ph & 5 & 5 & 5 & 5 & 5 & 5 & 5 & 5 & 5 & 5 \\
Kualitatif & & & & & & & & & & \\
$\quad$ Gerak massa & 2 & 2 & 2 & 2 & 2 & 2 & 2 & 2 & 2 & 2 \\
$\quad$ Warna & 3 & 3 & 3 & 3 & 3 & 3 & 3 & 3 & 3 & 3 \\
$\quad$ Konsistensi & 3 & 3 & 2 & 2 & 0 & 3 & 2 & 2 & 3 & 3 \\
$\quad$ Bau & 1 & 1 & 1 & 1 & 1 & 1 & 1 & 1 & 1 & 1 \\
Total & 41 & 42 & 41 & 41 & 41 & 42 & 42 & 42 & 42 & 42 \\
\hline
\end{tabular}

Hal ini sesuai dengan Peraturan Menteri Pertanian (2014) menyatakan bahwa bibit ayam yang unggul adalah tenak yang memiliki sifat unggal dan persyaratan tertentu untuk dikawinkan / dikembangbiakan. Sifat kualitatif dan kuantitatif dari spermatozoa yang baik akan berguna sebagai proses seleksi. Sifat-sifat yang baik dari calon pejantan dapat digunakan untuk menghasilkan keturunan yang lebih baik (Putra et al.. 2014).

\section{KESIMPULAN}

Seleksi pejantan ayam kampung lokal yang unggul dari penilain secara breeding value dari nilai yang tertingi dan yang dipilih adalah ayam 2, 6, 7, 8, 9 dan 10. Hal ini dikarenakan keenam pejantan ayam kampung lokal lebih unggul dari segi penilaian secara keseluruhan makroskopis dan mikroskopis dibandingkan dengan keempat pejantan lainnya. Perlu dilakukan seleksi ayam jantan yang lebih akurat untuk generasi berikutnya. Perlu penelitian lebih lanjut untuk mengetahui perhitungan secara keseluruhan dari segi mikroskopis yaitu konsentrasi dan daya hidup ayam kampung lokal.

\section{DAFTAR PUSTAKA}

Abdillah. 1996. Pengaruh Beberapa Pengencer Semen, Lama Penyimpanan Semen dan Waktu Inseminasi terhadap Fertilitas Spermatozoa Ayam Buras. Program Pascasarjana, Institut Pertanian Bogor, Bogor (Tesis).

Bahr, J. M. and M. R. Bakst. 1987. Poultry. In: E.S.E. Hafez (Ed). Reproduction in farm animal. $6^{\text {th }}$ Ed. Lea and Febiger, Philadelphia. Pp 375-379.
Bearden, H. J. and Fuquay. 1984. Applied Animal Reproduction. Reston Publishing Company Inc. Reston. Virginia.

Danang, D. R., N. Isnaini dan P. Trisunuwati. 2012. Pengaruh lama simpan semen terhadap kualitas spermatozoa Ayam Kampung dalam pengencer ringer's pada suhu $40^{\circ} \mathrm{C}$. Jurnal Ternak Tropika 13(1): 47-57.

Dudi. 2007. Pendugaan nilai pemuliaan dan tren genetik bobot badan prasapih Domba Priangan menggunakan Animal Model BLUP. Jurnal Ilmu Ternak. 7(2): 107112.

Ervandi, M. 2017. Motilitas dan abnormalitas spermatozoa bangsa pejantan setelah penyimpanan. Jurnal Ilmiah Media Publikasi Ilmu Pengetahuan dan Teknologi. 6(2): 113-119.

Etches, R. J. 1996. Reproduction in Poultry. Departement of Animal and Poultry Science. University of Guelph Ontario, Canada.

Evans, C.and Maxwell. 1987. Salomon's Artificial Insemination of sheep and Goats. Butter Woths Pty Ltd Collingwood. Victoria.

Garner, D. L., and E. S. E. Hafez. 1993. Spermatozoa and Plasma Seminal In Reproduction in Farm Animals (E.S.E. Hafez, Ed). $6^{\text {th }}$ Edition Lea and Febiger Philadelphia. Pp 165-187. 
Gilbert, A. B. 1980. Poultry. In: E.S.E. Hafez (Ed). Reproduction in farm animals. $4^{\text {th }}$ Ed. Lea and Febiger, Philadelphia. Pp 423-446.

Gunawan, A., M. Sulistyati, Budiman, M. Sulaeman dan K. M. Dayat. 2000. Sistem pengetahuan lokal cara seleksi Ayam Buras dan uji coba potensi produktivitasnya. Seminar Nasional Peternakan dan Veteriner. Hal: 185-188.

Hafez, E. S. E. 1993. Semen Evaluation. In: Hafez, E.S.E. (Ed.) Reproduction in Farm Animals. 6th ed. Lea \& Febiger, Philadelphia. Pp 405-423.

Hanum, M. 2001. Efektifitas Berbagai Jenis Pengencer terhadap Kualitas Semen Cair Ayam Lokal. Fakultas Kedokteran Hewan. Institut Pertanian Bogor, Bogor (Skripsi).

Hidajat, K. 2000. Pengaruh Berbagai Macam Pengencer dan Dosis Inseminasi terhadap Periode Fertil Sperma dan Daya Tetas Telur. Fakultas Pertanian, Universitas Padjajaran, Bandung (Skripsi).

Hijriyanto., M. Dasrul dan C. N. Thasmi. 2017. Pengaruh frekuensi penampungan semen terhadap kualitas spermatozoa pada Ayam Bangkok. Jurnal Ilmu Ternak dan Veteriner 1(1): 46 - 53.

Irastuti, 2007. Pengaruh Jenis Pengencer Semen terhadap Fertilitas dan Periode Fertile Spemetozoa Ayam. Jurusan Peternakan Fakultas Pertanian Universitas Tadulako, Palu (Skripsi).

Johari, S., Y. S. Ondho., S. Wuwuh., Y. B. Henry dan Ratnaningrum. 2009. Karakteristik dan kualitas semen berbagai galur Ayam Kedu. Fakultas Peternakan Universitas Diponegoro. Seminar Nasional Kebangkitan Peternakan. Tanggal 20 Mei 2009, Semarang.

Khairi, F., A. Muktiani dan Y. S. Ondho. 2014. Pengaruh suplementasi vitamin e, mineral selenium dan zink terhadap konsumsi nutrien, produksi dan kualitas semen Sapi Simental. Jurnal Agribisnis dan Peternakan 14(1): 6-16.

Kismiati, S. 1997. Pengaruh Interval Inseminasi terhadap Performan Reproduksi dan Heritabilitas Pertumbuhan Ayam Kedu Hitam. Program Pasca Sarjana Universitas Gadjah Mada, Yogyakarta (Tesis).

Mardalestari, R. 2005. Pengaruh Jenis dan Konservasi Krioprotektan serta Metode terhadap Kualitas Semen Beku Ayam Arab (Fayoumi). Program Studi Biologi, Universitas Pakuan, Bogor (Skripsi).

Nataamijaya A. G. 2010. Pengembangan potensi Ayam Lokal untuk menunjang peningkatan kesejahteraan petani. Jurnal Litbang Pertanian 29(4): 131-138.

Nugroho, A. P dan D. M. Saleh. 2016. Motilitas dan abnormalitas spermatozoa Ayam Kampung dengan pengencer ringer laktat-putih telur dan lama simpan pada suhu $5^{\circ} \mathrm{C}$ selama 48 jam. J. Acta. Vet. Indonesian 4(1): 35-41.

Octa, D., I. G. N. B. Trilaksana dan W. Bebas. 2014. Glukosa-astaxanthin meningkatkan motilitas dan daya hidup spermatozoa Ayam Kampung yang disimpan pada Suhu $3-5^{\circ} \mathrm{C}$. Indonesia Medicus Veterinus 3(1): 9-19.

Peraturan Menteri Pertanian Republik Indonesia. 2014. No 79/Permentan/OT.140/6/201. Tentang Pedoman Pembibitan Ayam Asli dan Ayam Lokal yang Baik. Jakarta.

Putra, W. P. B. Sumadi., T. Hartatik dan H. Saumar. 2014. Simulasi uji zuriat pada sifat pertumbuhan sapi Aceh. Jurnal Ilmu Ternak Universitas Padjadjaran. 14(1) : 12-16.

Rosyqoti, N. 2001. Pengaruh Frekuensi Penampungan terhadap Kualitas Semen Ayam Kampung. Universitas Diponegoro, Semarang (Skripsi).

Saleh, D. M. dan Sugiyatno. 2006. Pengaruh waktu inseminasi buatan terhadap fertilitas Ayam Petelur. Jurnal Produksi Ternak 83): 83-87. 
Salisbury, G. W. dan N. L. Van Demark. 1985. Fisiologi dan Inseminasi Buatan pada Sapi. Gadjah Mada University Press, Yogyakarta.

Sopiyana, S., S. Iskandar, T. Susanti dan D. Yogaswara. 2006. Pengaruh krioprotektan DMA, DMF, dan gliserol pada proses pembekuan semen Ayam Kampung. Seminar Nasional Teknologi Peternakan dan Veteriner. Bogor. Hal: 704-710.

Supriatna, I. 2000. Inseminasi Buatan pada Ayam. Kegiatan Pelatihan Inseminasi Buatan pada Ayam. Laboratorium Ladang Terpadu, Fakultas Kedokteran Hewan. Institut Pertanian Bogor, Bogor.
Suprijatna, E., U. Atmomarsono dan R. Kartasudadjana. 2005. Ilmu Dasar Tenak Unggas. Cetakan ke-1. Penebar Swadaya, Jakarta.

Toelihere, M. R. 1981. Inseminasi Buatan pada Ternak. Cetakan ke-VI. Angkasa. Bandung.

Toelihere, M. R. 1985. Inseminasi Buatan pada Ternak. Angkasa, Bandung.

Toelihere, M. R. 1993. Inseminasi Buatan pada Ternak. Angkasa. Bandung.

Yuwanta, T. 2004. Dasar ternak Unggas. Kanisius, Yogyakarta. 